\title{
How Family Business in SME Scale Alleviate Their Business Amid Pandemic
}

\author{
Andreas Wijaya $^{1 *}$, Sophia Reni Susilo ${ }^{1}$ \\ ${ }^{1}$ Faculty of Social Sciences and Humanities, Bunda Mulia University, Lodan Raya 12, Jakarta, Indonesia \\ *Corresponding author. Email: awijaya@bundamulia.ac.id
}

\begin{abstract}
The outbreak of Covid-19 pandemics has affected various aspects of human life and forced many businesses to close. The majority of SMEs in Indonesia endeavor to keep operating their business. Meanwhile, large-scale quarantines, restriction, and social distancing measures have been devastating several kinds of business. On one side, imposing people (consumers) to stay at home lowers their productivity, of which their purchasing power becomes unstable, because this situation hits hardly their revenues. In this research, such phenomenon was analyzed by using SWOT analysis to elucidate each component of S-O, W-O, S-T, W-T and provide the suggestions in order to survive their business. In conclusion, the flexibility of business gives advantages for family business in SME sector to substitute their products to earn profits, while the recession needs to be aware in order to save their finance.
\end{abstract}

Keywords: Covid-19, SMEs, Family Business, SWOT

\section{INTRODUCTION}

The World Health Organization declared a global public health emergency on January $30^{\text {th }}, 2020$. On February $11^{\text {th }}$, 2020 , WHO announced a new virus called "Covid-19". The spread of the virus is happening so fast that the exponential spread of COVID-19 in many countries have made an argue to embark on precautionary measures to subdue people transmission. Finally, in April 2020, each country's government imposed to take lockdown and quarantines action to cut down the contagion. However, the results were mixed for every country, for instance: data from [17] shows that Europe and Africa have successfully dwindling the cases, while the other continents such as Asia, South America, North America, and Australia still rose up their cases. Meanwhile, large-scale quarantines, restriction and social distancing measures had devastating several businesses. On one side, imposing people (consumers) to stay at home ensues low production and the demand becomes unstable, because this situation hits hardly their revenues [1]. On the other side, the unemployment levels rise sharply and even some companies reported that they had to get rid of their workers. As consequences, International Monetary Fund (IMF) in [12] reported that this condition has successfully brought a lot of countries to the brink of recession in Q1 2020, including Indonesia that was predicted to decrease between $-5 \%$ and $0 \%$. Looking more specifically, according to [11], in the past year SMEs played a vital role in Indonesia while contributing to national economy and providing workforce approximately for $97 \%$, whereas large enterprise merely absorbed $3 \%$ of the workers. In addition, the majority of business actors who contribute to the economy in Indonesia are SMEs, and most of them are family firms [14]. However, since the outbreak of COVID-19, this sector has been vulnerable. According to the report from [16], since the lockdown almost $75 \%$ of their income had been lost until August, and it was predicted that almost $50 \%$ of SMEs would survive until November. Businesses, including SMEs, will bear the brunt of a reduction in global demand for their products and services. SMEs may have less resilience and flexibility in dealing with the costs these shocks entail. Based on data, [13] and [9], the majority of SMEs in Indonesia are based on family business systems. In academic literature and managerial practice, it has the relevance of uniqueness in family firm structure during the crisis, [1] as an owner of family firm, they get consequences being hit twice during the crisis, as a citizen and the owner business, other factor from [2] in particular, family emotion can affect the performance during the crisis. Nonetheless, family firms exhibit distinctive features about their behavior and actions during a crisis. It has been shown that the increased family ownership can reduce the likelihood that a company will follow formal crisis procedures [1], which also revealed that because the ownership structure mostly consists of their family, it has a high flexibility system, altered decision, and quick responses to change, and is non-bureaucratic. For instance, several SMEs business in Indonesia have changing their main business to producing PPE, selling a medical stuff. Designing new strategies in COVID-19 situation becomes highly important to impede the crisis and keep sustain their business. A study from [3] suggested SWOT analysis to conduct in this changing environment. Moreover, this study aimed to investigate Strength, Weakness, Opportunity and Threat of family business in COVID-19 era. Therefore, a description and evaluation would be prepared to propose a framework. 


\subsection{Our Contribution}

The impact of the viruses is aggravating on health conditions concurrently with economic conditions, convinces salient issues to emphasis. Hence, this paper provides preliminary investigation on how family business survived after a crisis. The methodology of SWOT model has a purpose to address the salient area, diminish the risk, and expand their possible advantages with the opportunity to thrive their business.

\subsection{Paper Structure}

The other parts of this paper are organized as follows: Section 2 introduces an introduction to this paper, which includes a SWOT analysis; Section 3 presents the research method; Section 4 presents the results of the analysis or findings and discussion; and Section 5 concludes the paper and provides direction for future research.

\section{BACKGROUND}

Literally, SWOT analysis is a management tools to measure a gap between their internal and external factors. It was invented in the past by [10], the management consultant at the Stanford Research Institute, and being more adapted in almost all business areas. Therefore, [18] investigated SWOT into internal forces, such as: strengths category to describe about the positive of business in capitalization, leverage, or maintenance; weakness category as the opposite is the factor that needs to be emphasized, either to be mitigated or eliminated. On the other side of external forces, there are also positive and negative aspects, for instance: the demanding of potential area to invest or pursue are positive side to be categorized in opportunities; on the other side is threats category and mostly a negative side that need a concern to mitigate or shore up. Furthermore, [4] divided the result of SWOT analysis into four matrix. Firstly, the Strength-Opportunity strategy (S and O or Maximaxi) strategy in this combination is to harness the strengths of the opportunities identified. Secondly, WeaknessOpportunity Strategy (W and O or Mini-maxi) The opportunities that have been identified, cannot possibly be exploited due to the weakness of a company. Therefore, Strength-Threat strategy ( $\mathrm{S}$ or $\mathrm{T}$ or Maxi-min) in the analysis of threats, there is also a need to address them. This strategy is to try finding the strengths the company has that are used to reduce or counteract these threats. Lastly, Weakness-Threats Strategy (W and T or Mini-mini) in this situation, means that the company must face threats as well as internal weaknesses.

\section{RESEARCH METHOD}

The methodology of this research is derived from primary data, including field study, observation, interview, and secondary data to complete this study. During the safety compulsory measurement, we collected the data via telephone and e-mail. Each of respondent was given openended question regarding the Strength, Weakness, Opportunity, and Threat in order to get their responses. The sample was collected in a group discussion accounted for 30 owners of family business entrepreneurs in SME scale. Furthermore, the data was being evaluated using SWOT analysis to determine their strength, weakness, opportunity, and threat. Each indicator would be analyzed to meet the solution to provide the four-quadrant matrix: S-O, W-O, S$\mathrm{T}, \mathrm{W}-\mathrm{T}$ to be concluded through a discussion.

\subsection{List of Question}

List of Strength question.

What advantages does your company have? What makes your company better than others? What causes your company to get sales? What advantages do your customers look? What uniqueness does your company have?

\section{List of Weakness question.}

What should be improved in your company?

What should your company avoid?

What weaknesses do customers see or feel in your company?

What factors that can eliminate the sales of your company? What have your competitors done to make theirs better than yours?

List of Opportunity question.

What opportunities can you see?

What are the current trends that suit your business?

\section{List of Threat question}

What developments are a potential threat to your company? What obstacles are currently being faced?

What have your business competitors done?

Are there any changes from the government that could threaten the development of your business?

Are there any changes from the government that could threaten the development of your business?

\section{FINDINGS AND DISCUSSIONS}

In this section, the finding and discussion of SWOT are described in Table 1 below: 
Table 1 SWOT Matrix

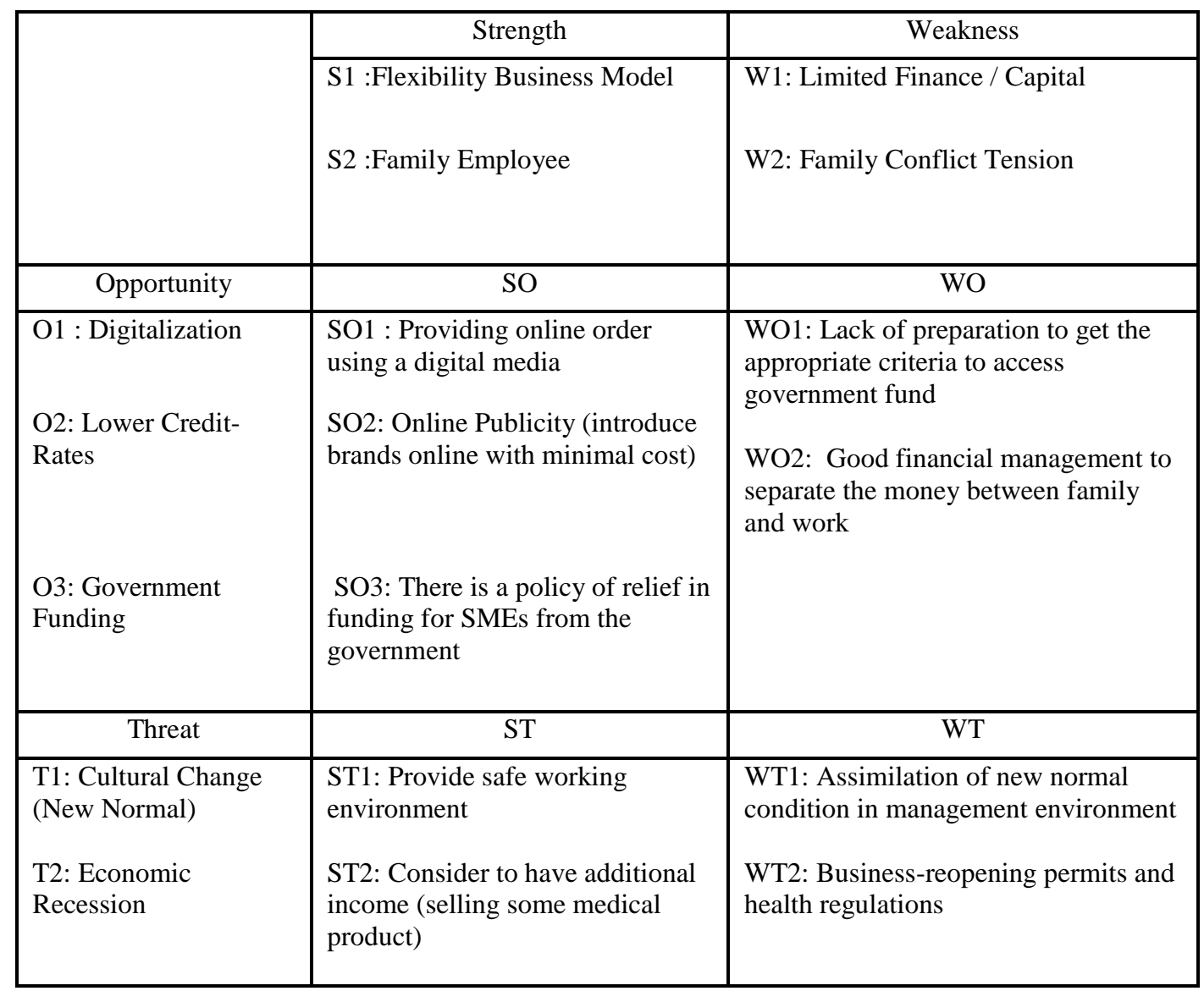

SWOT analysis series models the strategic processes found in four matrices. First, the Strength-Chance strategy (S and O or Maxi-maxi) makes use of the strengths of opportunities identified. Second, the Weakness-Opportunity Strategy (W and O or Mini-maxi). The identified opportunities cannot be exploited due to the weakness of a company. Therefore, the Strength-Threat strategy ( $\mathrm{S}$ or T or Maxi-min). In threat analysis, there is also a need to deal with it. This strategy tries to find the strengths the company has that are used to reduce or counteract these threats. Finally, the Threat-Weakness Strategy (W and T or Mini-mini). In this situation, the company must face both internal threats and weaknesses.

In the first section, combining of $\mathrm{S}-\mathrm{O}$ would create an innovation strategy to assist their business. According to [5], using social media can be easily explained to promote the company and product. Since the lockdown had been admitted, the awareness of online media had been soared in Indonesia. The distribution of grants from the government can help small and medium entrepreneurs to maintain their business. Lower credit-rate and relaxed credit-penalty given by Bank of Indonesia, will give a change in their business operation. Second, evaluating the weakness and opportunity at W-O category will generate a couple measurement to mitigate the crisis of COVID-19. Some businesses still do not have appropriate criteria to get access to the funding from government. The condition of unstable income and family tension indicate that the owners have to create good

\section{CONCLUSIONS}

The emerged of COVID-19 has been affecting wide range of human activities from the health problems to socio financial management in order to separate the income between business and family matters.

Looking from S-T categories, the combination of strength and threat creates a new way to mitigate the risk: Flexibility management system gives a rapid change to create a new culture and environment. Based on the recommendations from PWC, the majority of business need to follow the guideline "New Normal" rules. Lastly, W-T categories, the combination of strength and threat have provided the regulation to battering on COVID-19, while [1] considered a cultural change in business management system. Looking at this new normal measurement, the assimilation of new normal would be important during this era. Educating employees to use their mask, wash their hands, or wearing gloves, need to be concerned to avoid the virus spread. economic and business areas. In this research, the outlook of SMEs has been analyzed using SWOT matrix. There are numerous situations to be highlighted, Firstly, in S-O section, the restriction of interaction with each other has forced family firms to adapt the new digital workflows in 
managing their operations and selling their products. This finding is similar to previous study from [6], in which the flexibility of family business creates the opportunity to reassess business model in responding the crisis because of the tremendous increased number of internet usage. The other opportunity from State-Owned Enterprise (SOE) ministry plan gives the financial assistance for small business to survive in pandemic era such as cutting rates and relaxing repayment. According to [15], the amount of credit limit in government program accounted in US\$ 32,269 gives support for SMEs to struggle in their business. The current condition is also similar to South Korea [7], in which the government support would improve the survival and growth of SME business. However, looking into W-O section, the document for the requirement of bank loan still becomes a barrier to apply for credit, for instance: small business in kiosk must have business certificate regarding credit worthiness. In conclusion, the distribution of financial grant is spread unequally and this needs to be reassessed about the mechanism to approach all SME sectors in effective way. Otherwise, we also considered that family business needs to have a strict financial management to separate their money between business and family needs. In section W-T category, the new normal era imposed people to use protective equipment, such as face mask, face shield, and provide antiseptics in their workplace [1]. This guidance needs to be paid attention for some business to assimilate "new normal" to follow the rules in operating their business. Based on the government instruction, nowadays every single business in Indonesia need to take emphasis on the restriction of safety guideline. Furthermore, looking at S-T section, the damage of pandemic varies, while some business gets hit hard, some business is thriving, the outbreak of Covid-19 shows that the market changes rapidly, some business change their products into medical categories such as: healthcare medication, herbs, and vitamins [8]. This finding is also similar in the matter of flexibility of business model during the economic recession making business to substitute their products into medical categories to take additional income. In conclusion, the flexibility of business gives advantages for family business in SME sector to substitute their products and get their profits, while the recession needs to be aware in order to save their funds. Moreover, this study also suggests for future researcher to get in-depth analysis regarding several variables to strive the unforeseen crisis, for instance: how to mitigate repercussion from suspicious people and make less susceptible people in the workplace.

\section{REFERENCES}

[1] S. Kraus, T. Clauss, M. Breier, J. Gast, A. Zardini, and V. Tiberius, "The economics of COVID-19: initial empirical evidence on how family firms in five European countries cope with the corona crisis," International Journal Entrepreneurship Behavior, vol. 26, no. 5, pp. 1067-1092, 2020, doi: 10.1108/IJEBR04-2020-0214.
[2] R. Arrondo-García, C. Fernández-Méndez, and S. Menéndez-Requejo, "The growth and performance of family businesses during the global financial crisis: The role of the generation in control," Journal Family Business Strategy, vol. 7, no. 4, pp. 227-237, 2016, doi: 10.1016/j.jfbs.2016.11.003.

[3] C. Namugenyi, S. L. Nimmagadda, and T. Reiners, "Design of a SWOT analysis model and its evaluation in diverse digital business ecosystem contexts," Procedia Computer Sciences, vol. 159, pp. 1145-1154, 2019, doi: 10.1016/j.procs.2019.09.283.

[4] F. Hao, Q. Xiao, and K. Chon, "COVID-19 and China's Hotel Industry: Impacts, a Disaster Management Framework, and Post-Pandemic Agenda," Int. Journal Hospital Management, vol. 90, 2020, doi: 10.1016/j.ijhm.2020.102636.

[5] V. B. Rafiee and J. Sarabdeen, "Social media marketing: The unavoidable marketing management tool," Vis. 2020 Innov. Dev. Sustain. Econ. Growth Proc. 21 st International Business Information Management Association Conference IBIMA 2013, vol. 2, pp. 933-942, 2013.

[6] J. Fellenstein and A. Umaganthan, "Digital Transformation: How enterprises build dynamic capabilities for business model innovation - A multiplecase study within the logistics and transportation industry," Master Thesis, 2019, [Online]. Available: http://www.diva-portal.org/smash/get/diva2: 1320967/FULLTEXT01.pdf

[7] S. Park, I. H. Lee, and J. E. Kim, "Government support and small- and medium-sized enterprise (SME) performance: the moderating effects of diagnostic and support services," Asian Business Management, vol. 19, no. 2, pp. 213-238, 2020, doi: 10.1057/s41291-01900061-7.

[8] S. Verma and A. Gustafsson, "Investigating the emerging COVID-19 research trends in the field of business and management: A bibliometric analysis approach," Journal Business, vol. 118, pp. 253-261, 2020, doi: 10.1016/j.jbusres.2020.06.057.

[9] Wijaya, A. (2019) Metode Penelitian Menggunakan Smart PLS 03. 1st edn. Jakarta: Innosains.

[10] Humprey, Albert (December 2005). SWOT Analysis for a product Recall. Long Range.

[11] Bank Indonesia. (2015). Profil Bisnis UMKM. Retrieved August 13, 2020, from 
https://www.bi.go.id/id/umkm/penelitian/nasional/kajia n/Documents/Profil\%20Bisnis\%20UMKM.pdf

[12] BBC News. (2020). Resesi: 'Resesi ekonomi di depan mata' - ekonomi Indonesia menyusut tajam pada triwulan kedua, 'yang terburuk sejak dihantam krisis moneter 1998'. Retrieved August 13, 2020, from https://www.bbc.com/indonesia/indonesia-53152994

[13] IDN Times. (2020). Dampak COVID-19 ke Ekonomi Indonesia Lebih Ramah Dibanding Negara Lain. Retrieved August 13, 2020, from https://www.idntimes.com/business/economy/helmi/da mpak-covid-19-ke-ekonomi-indonesia-lebih-ramahdibanding-negara-lain/3

[14] Indonesia report family business survey. (2014). Survey Bisnis Keluarga 2014 Indonesia. Retrieved August 13,2020, from https://www.pwc.com/id/en/publications/assets/indones ia-report-family-business-survey-2014.pdf

[15] The Jakarta Post. (2020). Govt to provide interest subsidy for small borrowers as COVID-19 hits hard. Retrieved Sept 13, 2020, from https://www.thejakartapost.com/news/2020/04/22/govtto-provide-interest-subsidy-for-small-borrowers-ascovid-19-hits-hard.html

[16] LIPI. Survei Kinerja UMKM di Masa Pandemi COVID19. Retrieved August 14, 2020, from http://lipi.go.id/berita/survei-kinerja-umkm-di-masapandemi-covid19/22071

[17] Ourwolddindata.com. Statistics and Research Corona Virus Pandemic. Retrieved Sept 15, 2020, from https://ourworldindata.org/microbes-battle-sciencevaccines.

[18] David, Fred R. (2009). Manajemen Strategis: Konsep. Buku 1. Penerbit Salemba Empat. Jakarta. 